Науковий вісник Дьвівського націонадьного університету ветеринарної медицини та біотехнологій імені С.З. Гжицького

\author{
Scientific Messenger of Lviv National University \\ of Veterinary Medicine and Biotechnologies
}

\title{
Agriculture of Horodok District: Environmental and Economic Analysis and Perspectives
}

\author{
R.P. Paranjak, B.M. Kalyn, R.Yu. Kozynyak
}

Stepan Gzhytskyi National University of Veterinary Medicine and Biotechnologies Lviv, Ukraine

Article info

Received 29.01.2018

Received in revised form 28.02.2018

Accepted 06.03.2018

Stepan Gzhytskyi National University of Veterinary Medicine and Biotechnologies Lviv, Pekarska str., 50, Lviv, Ukraine. Tel.:+38-067-777-51-22 E-mail: kalynb@bigmir.net
Paranjak, R.P., Kalyn, B.M., \& Kozynyak, R.Yu. (2018). Agriculture of Horodok District: Environmental and Economic Analysis and Perspectives. Scientific Messenger of Lviv National University of Veterinary Medicine and Biotechnologies. 20(84), 77-82. doi: 10.15421/nvlvet8414

The article analyzes the state and dynamics of the main indicators of agricultural development in the Horodok district. The national economic and ecological aspects of the development of the complex and the factors influencing its condition were studied. It was indicated on the connection of the efficiency of agricultural production with the state of soils, water, infrastructure provision and the general state of the economy of the territory. The main negative impacts of intensive agricultural development on natural ecosystems and the state of the environment are outlined. The basic link of agrosphere in the region is agriculture. In the conditions of the Horodok distric, the main risks of the development of agriculture are related with a high proportion of land involved in agriculture, and a high indicator of their rooting: environmentally sustainable systems account for less than half of all land. In addition, the aggravated structure of agro industrial production is associated with the dominant role of plant growing, which is mainly represented by monocultures, which increases the need for mineral fertilizers and pesticides, enhances instability of agro ecosystems and increases the risk of contamination of surface water in the district. In terms of efficiency and productivity, the agro complex of the district is close to the regional average. Attention is need to the poor state of infrastructure provision and the potential problems of labor resources. Strategic directions of agrosphere development today are connected with the formation of rational, ecologically safe and sustainable land use development, and from the economic point of view it is necessary to develop the most effective directions. In order to ensure sustainable growth of the agricultural complex of the region, attention should be paid to the diversification of crop production, balanced support to the animal sub-sector, social and infrastructure problems, and to outline the directions of exit of enterprises of the district into world markets.

Key words: agrarian sector, environment, agroecosystem, soil, crop production.

\section{Сільське господарство Городоцького району: еколого-господарський аналіз та перспективи}

\author{
Р.П. Параняк, Б.М. Калин, Р.Ю. Козиняк \\ Львівський національний університет ветеринарної медицини та біотехнологій імені Гжиџького, \\ м. Львів, Україна
}

У статті досліджено стан та динаміку основних показників розвитку сільського господарства Городоцького району. Вивчено народно-господарські та екологічні аспекти розвитку комплексу та чинники, що впливають на його стан. Вказано на зв'язок ефективності сільськогосподарського виробництва зі станом трунтів, вод, інфраструктурного забезпечення та загальним станом економіки території. Окреслено основні негативні впливи інтенсивного розвитку сільського господарства на природні екосистеми та стан довкілля. Основною ланкою агросфери в регіоні є сільське господарство. В умовах Городоцького району основні ризики розвитку сільського господарства пов'язані з високою часткою земель, задіяних у сільському господарстві, та високим показником їх розораності: екологічно стійкі системи складають менше половини всіх земель. Крім того, порушена структура агропромислового виробництва пов'язана із домінуючою роллю рослинництва, котре в основному представлено монокультурами, ио підвишує потребу у мінеральних добривах та пестицидах, поглиблює нестабільність агроекосистем та веде до зростання ризиків забруднення поверхневих вод району. За ефективністю та продуктивністю агрокомплекс району близький до середніх по області показ- 
ників. Уваги потребує незадовільний стан інфраструктурного забезпечення та потенційні проблеми трудових ресурсів. Стратегічні напрями розвитку агросфери сьогодні пов'язані із формуванням раціонального, екологічно безпечного та стійкого розвитку землекористування, а з економічної точки зору необхідно розробити найбільш ефективні напрямки. Для забезпечення сталого зростання сільськогосподарського комплексу району варто звернути увагу на диверсифікацію продукиї рослинництва, збалансовану підтримку тваринної підгалузі, соціально-інфраструктурні проблеми та намітити напрямки виходу підприємств району на світові ринки.

Ключові слова: аграрний сектор, довкілля, агроекосистема, трунт, продукція рослинництва.

\section{Вступ}

Агросектор відіграє важливу роль у народногосподарському комплексі та в умовах Львівської області суттєво впливає на стан довкілля (Nahirniak et al., 2017; Smolynets et al., 2017). Перехід до ринкових умов господарювання підвищує вимоги до ефективності сектору загалом й продуктивності окремих господарств. Разом з тим інтенсифікація господарства повинна відбуватись за дотримання загальних принципів забезпечення сталого розвитку, що особливо актуально у світлі зростання споживання та збільшення антропогенного навантаження на агроекосистеми (Matsuska et al., 2017).

Еколого-економічні перспективи розвитку сільського господарства адміністративно-територіальних одиниць залежить від низки локальних умов: географічних, економіко-господарських, соціальних та екологічних (Nahirniak and Kalyn, 2017; Dorosh-Kizym et al., 2017). Якщо економічні показники сільського господарства території є цільовими параметрами максимізації параметрів конкурентоспроможності, то екологічні проблеми є обмеженнями, що дозволяють 3 множини напрямів розвитку господарства вибрати такі, які розвиватимуть сектор, не завдаючи шкоди довкіллю. Сукупність умов, що забезпечують розвиток господарства, відомі під назвою виробничого потенціалу галузі й суттєво залежать від території. Тому актуальним питанням $є$ вивчення особливостей та пов'язаних перспектив розвитку аграрного сектору для конкретних територіально-виробничих комплексів. Виявлені взаємозв'язки лежать в основі розробки перспективних планів розвитку конкретної території.

Аналіз останніх досліджень $і$ публікацій. Проблемам та перспективам розвитку сільського господарства приділили увагу багато дослідників, що закономірно $з$ огляду на важливість цієї галузі у нашій державі. Серед них І.П. Борейко, О.М. Бородіна, О.О. Веклич, О.Д. Гнаткович, С.I. Дем'яненко, М.В. Зубець, С.М. Колотуха, Н.А. Мазур, М.А. Мартинюк, П.П. Панченко, Т.М. Ратошнюк, В.П. Славов, О.М. Шпичак та інші. Особливої уваги заслуговують вивчення ролі інновацій у агросфері, інституціональні питання та проблема інвестицій, а також екологічні проблеми. Останні пов'язані з одного боку з впливом конкретних технологій на довкілля (наприклад, проблеми пестицидного та нітратного забруднення, ерозії грунтів тощо), з іншого боку - напрямами розвитку, що сприяють стійкому розвитку агросфери в цілому або окремих іiі елементів - виробничих чи переробних підприємств (наприклад, елементи органічного сільського господарства). Проблеми становлення органічного агровиробництва та стійкого землеробства в Україні розглядали В.Ф. Сайко, О.Т. Дудар, Ю.Ю. Мороз, Н.В. Зіновчук, В.Г. Потапенко,
Я.В. Мандибура та багато інших. Окремим блоком йде напрям досліджень, присвячений екологічній безпеці сільського господарства. Тут можна згадати праці В.В. Глухої, Т.О. Костюка, О.О. Ткачука, Т.В. Сокольської, І. Черевка та інших.

Цільові дослідження екологічних проблем сільського господарства та загалом агросфери Львівської області чи окремих іiі районів можна знайти у роботах К.В. Васьківської, І.В. Сембай, О.В. Паленичак, В.А. Чемерис, В.І. Душки, Л.І. Воркуна, Л.К. Демковича, I.В. Щербатої, Є.В. Бутенка, М.Л. Бозняка та інших.

У роботах Н.I. Біляк (Biliak, 2012; Biliak, 2014) розглянуто економічні та конкурентні аспекти розвитку сільського господарства Львівщини. Автором висловлено думку, що область не має конкурентних переваг у аграрній сфері, причиною чого $є$ роздрібненість виробництва, малий приток інвестицій та незадовільне матеріально-технічне забезпечення (Biliak, 2012). Зазначено, що для підвищення інвестиційної привабливості сільських територій слід втілити систему заходів на різних рівнях. Серед пропонованих заходів формування позитивного інвестиційного іміджу; створення сприятливого інвестиційного середовища, поширення інформації щодо інвестиційного потенціалу сільських територій області; підвищення ефективності управління інвестиційними ресурсами; впровадження інвестиційних проектів щодо підвищення рівня ефективності експлуатації автотранспортної мережі, у сфері розвитку туристично-рекреаційного бізнесу, в аграрній сфері та у сфері розвитку соціально-побутової інфраструктури; вдосконалення нормативно-правового та інституційного середовища інвестиційної діяльності в області; розвиток бізнесінфраструктури (Biliak, 2014).

Дослідження сільського господарства і пов'язаних 3 його діяльністю екологічних проблем на території Городоцького району практично відсутні, що підкреслює актуальність даного дослідження.

За загальноекономічним розвитком сільських територій Городоцький район 3 балом 0,548 посідає 11 місце серед 20-ти районів області (найвищий розвиток у Пустомитівському районі, 0,754; найнижчий - у Сколівському районі, 0,273). За наведеними оцінками інвестиційної привабливості Городоцький район потрапляє у групу середньої інвестиційної привабливості поряд із Золочівським, Жидачівським, Сколівським, Дрогобицьким та Старосамбірським районами.

Як свідчать статистичні дані (Baza danykh Holovnoho upravlinnia statystyky) та окремі наукові розробки (Berezivskyi, 2013), для сільського господарства Львівської області та іï окремих районів є характерним зростання виробництва продукції та підвищення його ефективності, хоча в окремих галузях (наприклад, виробництво телятини) - спад. Причини 
такої динаміки у (Berezivskyi, 2013) пов’язані з організаційно-економічними трансформаціями у розвитку сільськогосподарського виробництва підприємств цієї сфери. Водночас регіональна специфіка аграрного виробництва області зумовила значний розвиток особистих селянських господарств, що має великий вплив на функціонування сільськогосподарських підприємств.

На розвиток багатьох районів області суттєво впливає специфіка прикордонного розташування області. У роботі (Prytula et al., 2014) виділено групи прикордонних та транзитних районів, Городоцький район віднесено до другої групи. Висловлено думку, що людський потенціал сільських територій Львівщини перебуває у точці біфуркації власної реалізації, а першочерговими заходами поліпшення ситуації $є$ вдосконалення інфраструктурного та інформаційного забезпечення, використання сучасних інструментів управління розвитком територій, таких як стратегування та територіальний маркетинг для підвищення інвестиційної привабливості та залучення нових інвестиційних проектів у ці території. Певну, хоча й недостатню, роботу з вирішення цих завдань виконує районна адміністрація (Horodotska raionna derzhavna administratsiia). Зазначимо, що на офіційному сайті бракує інформації про інвестиційні проекти загалом та стосовно сільського господарства зокрема.

В умовах Львівської області вплив сільськогосподарської діяльності на довкілля проявляється передусім у дифузному (для земель, задіяних у рослинництві) та точковому (для підприємств тваринництва) забрудненні грунтів та поверхневих вод (Trysniuk, 2008), а також впливу землеробства на стан грунтів, що сприяє їх ерозії (Oliinyk and Bielova, 2014). Земельні ресурси значної частини Львівської області загалом схильні до деградації, що обумовлено рельєфними особливостями Прикарпаття. Тут внаслідок надмірного антропогенного освоєння, зокрема високої розораності та екстенсивного використання продуктивних угідь, значного поширення набули деградаційні процеси грунтового покриву. У Львівській області за даними (Baza danykh Holovnoho upravlinnia statystyky) у 2015 році з 2,183 млн. га загальної земельної площі сільськогосподарські землі становлять 1,29 млн га або 59\%. 3 них 794121 га (36\%) - рілля, 255828 га (12\%) пасовища, 187640 га (9\%) - сіножаті і найменше 23242 га (1,1\% від загальної площі) - багаторічні насадження. Дещо нижчий відсоток сільськогосподарських земель, у тому числі ріллі, у південних передгірських районах області. Проте тут фактором ризику стає складний рельєф та значна крутість схилів у агроландшафтах, що робить їх вразливими до ерозії. Активізація процесів донної та бічної ерозії на території області спостерігаються в основному по площі Передкарпатського прогину та Складчастих Карпат (Ekolohichnyi pasport Lvivskoi oblasti, 2017). Тут варто зазначити, що рельєф Городоцького району є рівнинний (Andreiko, 2001). При цьому рівнини Городоччини за висотою над рівнем океану належать до височин, а за зовнішньою будовою - до хвилястих горбисто-увалистих та зандрових рівнин. На півночі району розташоване пасмо Розточчя (абсолютні висоти 290 м i більше). Південна ж частина району знижена і зайнята заплавою Дністра з висотами 256-262 м.

\section{Результати та їх обговорення}

Загальна площа земель Городоцького району становить 56399 га, у районі є 55244 га сільськогосподарських угідь, 3 яких 36871 га - рілля (Baza danykh Holovnoho upravlinnia statystyky). Сільськогосподарські землі займають значну частку $(77,7 \%)$ усіх земель, тимчасом як так звані екологостабільні комплекси помітно менше, наприклад, ліси - 13,0\%. На території району нараховують 27 діючих сільгосппідприємств різних форм власності, 3 них 17 господарств займаються рослинництвом, 8 - рослинництвом і тваринництвом, 2 - садівництвом, 2 - тваринництвом (Horodotska raionna derzhavna administratsiia).

Важливими передумовами для розвитку сільського господарства є грунти, кліматичні та гідрологічні умови. Гідрологічна мережа району розвинена: характерними $\epsilon$ наявність доволі великої кількості ставків, розташованих 3 півночі на південь уздовж річки Верещиці. Ступінь водозабезпечення району достатній. Єдина велика річка району - Дністер з численними притоками та каналами поблизу сіл Мости, Монастирець, Грабине, Тершаків. Клімат району помірно континентальний, коефіцієнт зволоження більший ніж 1,1. Основними грунтоутворюючими породами на території району є лесовидні суглинки, алювіальні, делювіальні і водно-льодовикові відклади (Andreiko, 2001). Серед опідзолених лісових грунтів найбільш поширеними $є$ темно-сірі опідзолені і темно-сірі оглеєні грунти. Разом з опідзоленими чорноземами вони становлять 57,6\% грунтового покриву району. На півдні району зосереджені лучні грунти, смугою через увесь район уздовж р. Верещиці та у напрямі Львова між селами Мшаною та Рудним трапляються торфово-болотяні грунти. Загалом грунти району можна характеризувати як помірно та слабородючі. У господарствах району є значні площі кислих грунтів. Слабокислі грунти становлять 21,1\% грунтового фонду, середньокислі - 9,4\%, сильнокислі - 1,2\%. Негативними природними процесами і явищами на території Городоцького району вважаються ерозія, заболочування і підтоплення грунтів, зсуви, розливи річок, карст, який найпоширеніший у лісових масивах поблизу Великого Любіня.

Характеристика грунтів за вмістом гумусу, азоту, фосфору та калію за результатами агрохімічної паспортизаціï (Ekolohichnyi pasport Lvivskoi oblasti, 2017) за минулі роки дозволяє стверджувати, що середній вміст гумусу у грунтах району незначно нижчий від середньообласного показника (табл. 1).

Тут помітно менше грунтів із низьким й дуже низьким вмістом гумусу, проте й практично немає грунтів iз дуже високим вмістом (по області грунтів із дуже високим вмістом найбільша частка у Золочівському $18,8 \%$ та Сокальському районах - 17,2\%). Таким чином, з огляду на вміст гумусу, грунти у районі непогані. Щодо вмісту азоту, що легко гідролізується, то показники грунтів району дещо кращі $(129>118)$, аніж в середньому по області. Грунти Городоцького району відносно багаті на рухомі сполуки фосфору, вміст же 
рухомих сполук калію у Городоцькому районі незначно відрізняється від параметрів грунтів області.

Господарсько-економічні показники діяльності сільського господарства Городоччини. Нижче проведемо аналіз динаміки показників роботи аграрного сектору Городоцького району на основі даних статис- тики (Baza danykh Holovnoho upravlinnia statystyky) та окремих публікацій. Зазначимо передусім, що в економіці Городоччини домінує сільське господарство, основний його напрямок - рослинництво (принаймні так випливає 3 сумарної грошової оцінки виробленої продукції за всі роки, наведені на рис. 1).

\section{Таблиця 1}

Характеристика грунтів за вмістом гумусу (Ekolohichnyi pasport Lvivskoi oblasti, 2017)

\begin{tabular}{lccccccc}
\hline & \multicolumn{9}{c}{ площа грунтів, \% } \\
\cline { 2 - 7 } & дуже низький, & низький, & середній, & підвищений, & високий, & дуже високий, середньозважений \\
& $<1$ & $1,1-2,0$ & $2,1-3,0$ & $3,1-4,0$ & $4,1-5,0$ & $>5$ & показник, \% \\
\hline Городоцький район & 1,4 & 21,7 & 32,2 & 26,9 & 16,4 & 1,4 \\
Усього по області & 3,6 & 30,4 & 31,5 & 16,7 & 7,4 & 10,4 & 2,6 \\
\hline
\end{tabular}

Бачимо деяке зростання у рослинництві після 2010 року й практично стагнацію у тваринництві. Якщо ж врахувати показники інфляції (у період 2013-2017 гривня значно знизила свою вартість), то ріст рослинництва не такий уже й значний, а тваринництво переживає значний занепад. За багатьма іншими показниками можна також спостерігати перебіг кризових явищ у аграрній сфері району.

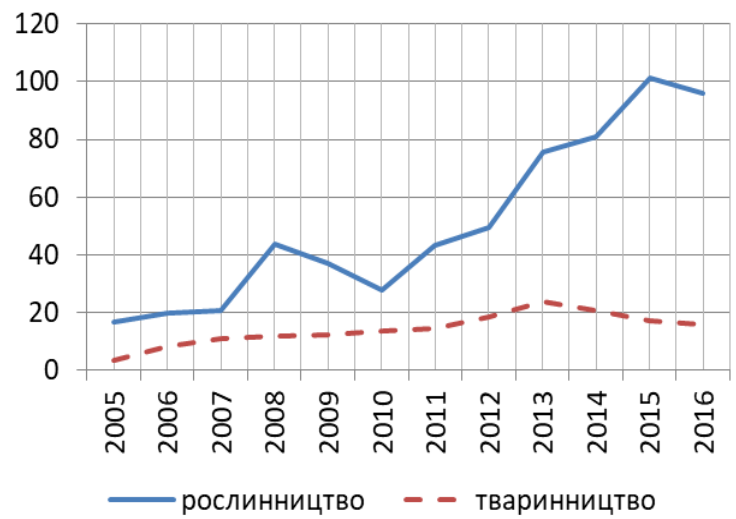

Рис. 1. Обсяги сільськогосподарської продукції Городоцького району, млн грн
Оскільки за багатьма категоріями по району немає даних за останні роки, на наступній діаграмі показано структуру реалізації продукції с.-г. по області у 2016 році щодо видів продукції, яка була облікована статистично (рис. 2).

У Городоцькому районі дані щодо картоплі та овочевих культур за 2014-2015 роки Управління статистики не оприлюднює з метою забезпечення виконання вимог Закону України «Про державну статистику» щодо конфіденційності інформації. Виробництво цукрового буряку, згідно з тим же джерелом, відсутнє з 2010 по 2016 роки, виробництво інших культур за цей же період епізодичне, за винятком зернових. Виробництво останніх - нестабільне (табл. 2) коефіцієнт варіації даних за 12 років становить $122,8 \%$.

У 2014-2016 роках у районі різко зросло виробництво озимого ячменю та впало практично до нуля виробництво кукурудзи. Основною зерновою культурою району продовжує залишатись озима пшениця, виробництво якої становило до 60\% усіх зернових. У 2006-2014 із нею успішно конкурувала кукурудза, щорічне виробництво цих культур складало 1020 тис. тонн на рік.

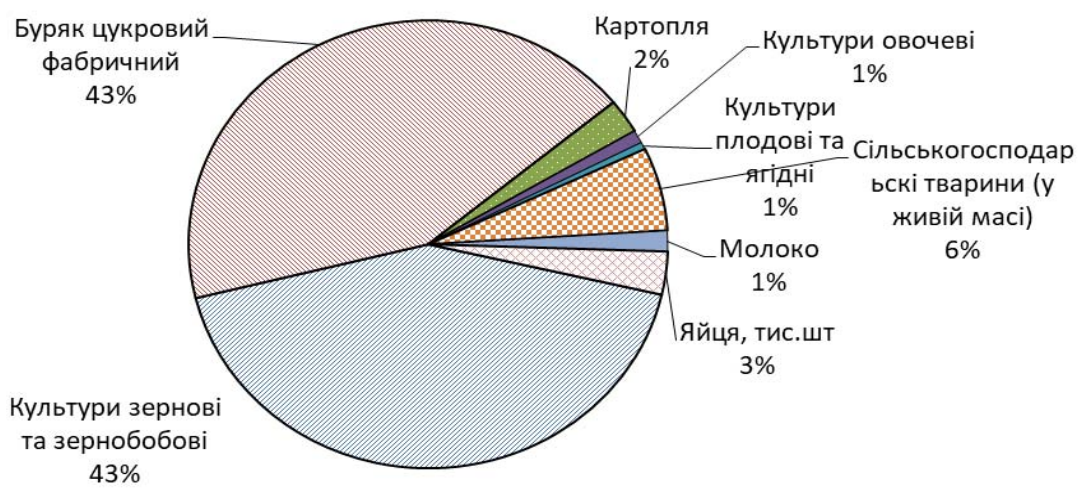

Рис. 2. Обсяги реалізації сільськогосподарської продукції підприємствами (крім малих) у 2016 р.

Ще 15 років тому основними сільськогосподарськими тваринами у районі була велика рогата худоба, кількість якої стрімко зменшувалась. 32009 року основну частку виробництва зайняло свинарство.
Загалом сьогодні у Городоцькому районі порівняно із середнім по області виробляють доволі мало яловичини, телятини і свинини у живій вазі, а також доволі багато молока та м'яса птиці. 
Таблиця 3

Обсяги реалізації зернових та зернобобових культур сільськогосподарськими підприємствами (крім малих) Городоцького району, тонн (Baza danykh Holovnoho upravlinnia statystyky)

\begin{tabular}{cccccccccccc}
\hline 2005 & 2006 & 2007 & 2008 & 2009 & 2010 & 2011 & 2012 & 2013 & 2014 & 2015 & 2016 \\
\hline 4237 & 2524 & 1459 & 2012 & 2019 & 1427 & 747 & 2696 & 3830 & 22079 & 6905 & 6946 \\
\hline
\end{tabular}

Стан сільського господарства території, окрім фізико-географічних параметрів, суттєво залежить від загального рівня розвитку виробничого потенціалу, важливим елементом якого є забезпеченість трудовими ресурсами та горизонтальні господарські зв'язки. Статистика свідчить, що після 2000 року відбулось різке падіння кількості найманих працівників підприємств-суб'єктів підприємницької діяльності, зайнятих у сільському господарстві району (рис. 3).

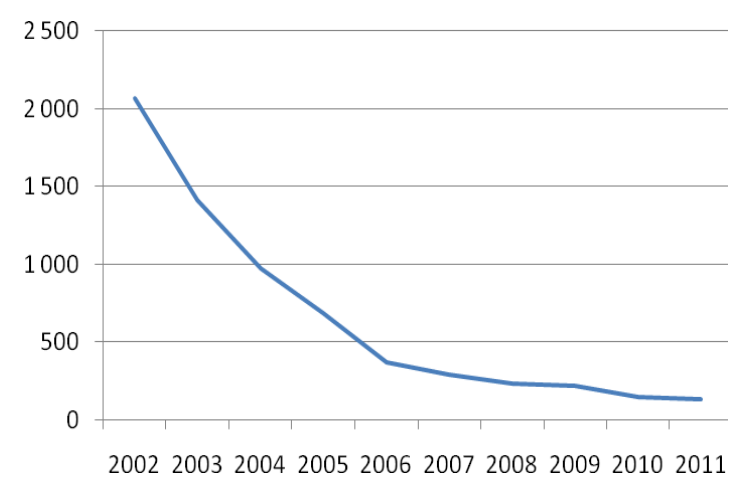

Рис. 3. Кількість найманих працівників підприємствами-суб' єктами підприємницької діяльності, зайнятих у сільському господарстві Городоцького району

(Baza danykh Holovnoho upravlinnia statystyky)

Екологічні аспекти діяльності сільського господарства Городоччини. В агропромисловому виробництві, в земле- й водокористуванні взаємоузгодження інтересів і вимог екології та економіки має надзвичайно велике значення, оскільки тут господарська діяльність здійснюється на великих територіях, є прямо й безпосередньо пов'язаною з використанням природних та біологічних ресурсів, втручанням у екосистеми, свідомим впливом на природні процеси. Загалом екологічна ситуація у районі не найкраща. Довкілля потерпає від забруднення атмосфери, поверхневих вод та земельних ресурсів.

За викидами забруднюючих речовин в атмосферне повітря від стаціонарних джерел забруднення у роз-

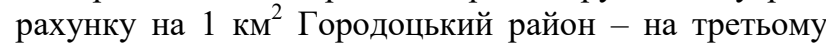
місці після Сокальського та Стрийського. Нагромадження відходів також негативно впливає на роботу агросектору. Наявність забруднюючих речовин негативно впливає на стан фітоценозів. У районі - шість звалищ побутових відходів. До поширених екологічних проблем рослинництва відносять й ерозію грунтів. Частково допомагають стабілізувати ерозійні процеси наявні тут ставки. Крупномасштабна меліорація у другій половині минулого століття призвела до осушення 51,4\% усіх земель сільськогосподарського призначення в районі.
Стратегічні ж напрями розвитку агросфери сьогодні пов'язані із формуванням раціонального, екологічо безпечного та сталого розвитку землекористування (Hutorov, 2010). Розуміння поняття «раціональне використання землі» повинне базуватися на врахуванні різних аспектів землекористування та передбачення організованого для конкретних умов простору і часу оптимального способу ефективного використання землі, підвищення родючості грунтів, збереження екологічної рівноваги в природі. Деградація та забруднення навколишнього природного середовища - це наслідки надмірного залучення землі до використання в аграрній сфері, зростання антропотехногенних навантажень до критичних рівнів, порушення екологічно допустимих співвідношень між первісною природою і сільськогосподарськими угіддями. Тому першочерговим завданням є оптимізація агроландшафтів за екологічною стійкістю.

3 економічної точки зору варто розвивати найбільш результативні напрями. У рослинництві це пов'язано 3 урожайністю. Втілення екологоекономічних інновацій у сільське господарство допоможе стабілізувати ситуацію. До таких напрямків відносять поширення принципів природноландшафтної організації сільських територій, формування адаптивних систем землеробства, поліпшення якісних характеристик грунтів і загалом екологізацію сільськогосподарського землекористування.

\section{Висновки}

Базовою ланкою агросектору є сільське господарство, а основними виробничими галузями - рослинництво та тваринництво, яким належить вирішальна роль у забезпеченні населення продовольчими товарами. Екологічний аспект діяльності агросектору пов'язаний із впливом сільського господарства на природні екосистеми. Даний вплив є дуже масштабний, особливо у нашій країні у зв'язку із високою часткою земель, задіяних у сільському господарстві. 77,7\% усіх земель Городоцького району становлять сільськогосподарські землі. Вміст гумусу у грунтах району нижчий, а азоту, фосфору й калію - вищий, порівняно $з$ середнім по області. Агросектор району має виразне спрямування в бік рослинництва. За показниками продуктивності земель район знаходиться посередині списку районів Львівської області.

До проблем агросектору району можна віднести значне зменшення трудових ресурсів, задіяних у ньому, порушення балансу між окремими галузями, зокрема тваринництва, нестабільні показники врожайності у рослинництві, несприятливі екзогенні геологічні процеси, високий рівень розораності територіі. Перспективи сталого розвитку агросектору району пов'язані із 
розширенням асортименту випуску продукції рослинництва, інтенсифікацією розвитку тваринництва, вирішенням соціальних та інфраструктурних проблем, інтегруванням у світові ринки, зменшенням антропогенного навантаження та оптимізацією агроекосистем.

\section{References}

Andreiko, I.M. (2001). Pryroda Horodochchyny. Lviv: VNTL (in Ukrainian).

Baza danykh Holovnoho upravlinnia statystyky u Lvivskii oblasti. Rezhym dostupu: http://database.ukrcensus.gov.ua/statbank_lviv/Dialog /statfile.asp?lang=1. (in Ukrainian).

Berezivskyi, P. (2013). Orhanizatsiino-ekonomichni transformatsii rozvytku silskohospodarskoho vyrobnytstva $\mathrm{u}$ riznykh orhanizatsiino-pravovykh formakh hospodariuvannia Lvivskoi oblasti. Visnyk Lvivskoho natsionalnoho ahrarnoho universytetu. Ser: Ekonomika APK. 20(1), 3-14 (in Ukrainian).

Biliak, N.I. (2012). Otsinka konkurentospromozhnosti silskoho hospodarstva Lvivskoi oblasti. Naukovyi visnyk LNUVMBT im. S.Z. Gzhytskoho. 14, 1(51), 59-65 (in Ukrainian).

Biliak, N.I. (2014). Otsinka investytsiinoi pryvablyvosti silskykh terytorii Lvivskoi oblasti. Visnyk Lvivskoho natsionalnoho ahrarnoho universytetu. Seriia: Ekonomika APK. 21 (1), 206-212 (in Ukrainian).

Dorosh-Kizym, M., Dadak, O., \& Gachek, T. (2017). Innovations in the agricultural sector of Ukraine in the context of the development of european integration. Scientific Messenger LNUVMB. 19(81), 123-128. doi: 10.15421/nvlvet8122

Ekolohichnyi pasport Lvivskoi oblasti (2017). Kolektyv avtoriv. Lviv (in Ukrainian).

Horodotska raionna derzhavna administratsiia: ofitsiinyi veb-sait. Rezhym dostupu: http://www.gorodokvlada.go v.ua/ (in Ukrainian).
Hutorov, O.I. (2010). Problemy staloho zemlekorystuvannia u silskomu hospodarstvi: teoriia, metodolohiia, praktyka: monohrafiia. X.: KhNAU (in Ukrainian).

Matsuska, O.V., Kalyn, B.M., \& Pavlyuk, I.O. (2017). The comparative analysis of the use of natural sorbents in wastewater cleaning processes in agricultural industry. Scientific Messenger LNUVMB. 19(79), 159-162. Rezhym dostupu: https://nvlvet.com.ua/index.php/journal/article/view/1 279

Nahirniak, T.B., \& Kalyn, B.M. (2017). Research of main problems of the natural reservoir fund of the Lviv region and the ways of their solvency. Scientific Messenger LNUVMB. 19(79), 105-110. doi:10.15421/nvlvet7921

Nahirniak, T.B., Grabovsky, R.S., \& Hrytsyna, M.R. (2017). Ecological and economic aspects of rational use and protection of land resources in Ukraine. Scientific Messenger LNUVMB. 19(79), 111-116. doi:10.15421/nvlvet7922

Oliinyk, V.S., \& Bielova, N.V. (2014). Erodovanist zemel v ahrolandshaftakh Peredkarpattia. Heopolityka i ekoheodynamika rehioniv: naukovyi zhurnall. Simferopol. 10(2), 360-369 (in Ukrainian).

Prytula, Kh.M., Bas-Yurchyshyn, M.A., Zlydnyk, Yu.R., \& Krupin, V.Ie. (2014). Formuvannia priorytetnykh napriamiv rozvytku prykordonnykh silskykh terytorii Lvivskoi oblasti. Sotsialno-ekonomichni problemy suchasnoho periodu Ukrainy. 4, 3-10 (in Ukrainian).

Smolynets, I., Olenych, I., Hariv, I., \& Gutyj, B. (2017). Entrepreneurship in agriculture. Scientific Messenger of LNU of Veterinary Medicine and Biotechnologies. 19(81), 56-63. doi: 10.15421/nvlvet8109

Trysniuk, I.V. (2008). Ekolohichna bezpeka ahroekosystem Prykarpattia. Naukovi zapysky Vinnytskoho derzhavnoho pedahohichnoho universytetu. Ser. Heohrafiia. 17, 118-123 (in Ukrainian). 